\title{
Detection on four continents of dengue fever cases related to an ongoing outbreak in Luanda, Angola, March to May 2013
}

E Schwartz ${ }^{1}$, E Meltzer (meltzere@zahav.net.il) ${ }^{1}$, M Mendelson ${ }^{2}$, A Tooke $^{3}$, F Steiner ${ }^{4}$, P Gautret $^{5,6}$, B Friedrich-Jaenicke ${ }^{4}$,

M Libman', H Bin ${ }^{8}$, A Wilder-Smith 9 , D J Gubler ${ }^{10}$, D 0 Freedman ${ }^{11}$, P Parola ${ }^{5,6}$

1. Center for Geographic Medicine and Department of Medicine C the Sheba medical center, Tel Hashomer \& Sackler School of Medicine, Tel Aviv, Israel

2. Division of Infectious Diseases \& HIV Medicine, Department of Medicine, Groote Schuur Hospital, University of Cape Town, South Africa

3. Department of Medicine, 2 Military Hospital, Wynberg, Cape Town, South Africa

4. Institut für Tropenmedizin und Internationale Gesundheit Charité - Universitätsmedizin Berlin, Germany

5. Assistance Publique Hôpitaux de Marseille, CHU Nord, Pôle Infectieux, Institut Hospitalo-Universitaire Méditerranée Infection, Marseille, France

6. Aix Marseille Université, Unité de Recherche en Maladies Infectieuses et Tropicales Emergentes (URMITE), Faculté de Médecine, Marseille, France

7. J.D. MacLean Centre for Tropical Medicine, McGill University Health Centre Montreal, Quebec Canada

8. The Central Virology Laboratory, Ministry of Health, Tel Hashomer Israel

9. Institute of Public Health, University of Heidelberg, Germany

10. Program on Emerging Infectious Diseases- Duke-NUS Graduate Medical School, Singapore

11. University of Alabama at Birmingham, Birmingham, Alabama, USA

In April 2013, ten cases of dengue fever in travellers returning from Luanda, Angola, to five countries on four continents, were reported to the globally distributed GeoSentinel Surveillance network. Dengue virus serotype 1 was identified in two cases. The findings indicate that a major dengue outbreak is currently ongoing in Luanda. This report illustrates how cases from an emerging arboviral epidemic focus can spread internationally and highlights the risk of dissemination of a vector-borne disease into receptive areas.

GeoSentinel provides a sentinel sample of returning travellers at 56 clinics in 24 countries on six continents [1]. During April 2013, GeoSentinel sites in Canada, France, Germany, Israel and South Africa reported a total of 10 cases of dengue in business travellers returning from Angola, with Luanda as the only likely place of exposure. Meanwhile, on $15 \mathrm{April}$, the Instituto de Higiene e Medicina Tropical in Lisbon, Portugal reported 19 cases of dengue acquired in Luanda since late March 2013, in four of whom dengue virus (DENV)-1 was detected by polymerase chain reaction (PCR) [2]. The nearly simultaneous reports of dengue cases related to travel to Luanda from five GeoSentinel sites on four continents, as well as Portugal, suggest that a large scale outbreak of dengue may in fact be unfolding in Angola.

\section{Background}

In Angola, DENV activity has been reported sporadically. Early surveys in the 1960 s revealed no evidence of DENV activity [3], while outbreaks of clinically suspected dengue in the 1970 s were proven to be caused by chikungunya [4]. In the 1980 s an outbreak of dengue was reported from Luanda, with subsequent reports of travel-related dengue acquired in Angola, by travellers from the Netherlands [5] and Brazil [6]. For a Brazilian travel-related case, the serotype identified was DENV2. Since then, there has been little information on the risk of dengue in Angola. This may represent an absence of disease activity, or a lack of awareness, diagnostic resources and active surveillance.

Travellers may serve as sentinels to local epidemic risks, and this role is especially important in areas with scarce public health reporting and resources. Thus, cases of dengue among European travellers returning from the Comoros islands in east Africa [7] and Benin in west Africa [8] have called attention to local DENV transmission. In a recent review, 12 of 27 countries in Africa where travellers/expatriates had acquired dengue, had not reported local DENV transmission [9].

Here, we report on an apparent outbreak of dengue in Luanda, Angola diagnosed among travellers presenting to travel clinics on four continents. 
Travel-related dengue infections acquired in Luanda, Angola, reported from GeoSentinel sites, March-May 2013 (n=10)

\begin{tabular}{|c|c|c|c|c|c|}
\hline Country of origin of the case & Fever onset date & $\begin{array}{l}\text { Time from fever onset } \\
\text { to test (days) }\end{array}$ & NS1 & Serology-IgM & Qt-PCR \\
\hline Germany & 30 March & 4 & Positive & Positive & ND \\
\hline Canada & 3 April & 10 & Negative & Positive & ND \\
\hline France & 5 April & 12 & Negative & Positive & Negative \\
\hline Germany & 7 April & 14 & Negative & Positive & ND \\
\hline South Africa & 10 April & 7 & ND & Positive & Negative \\
\hline Israel & 11 April & 14 & ND & Positive & ND \\
\hline Israel & 17 April & 7 & Positive & Positive & ND \\
\hline Israel & 18 April & 4 & Positive & Positive & DENV-1 \\
\hline Israel & 25 April & 5 & Positive & Positive & DENV-1 \\
\hline Israel & 2 May & 6 & Positive & Positive & ND \\
\hline
\end{tabular}

DENV: dengue virus; NS1: non-structural protein 1; ND: not done; Qt PCR: quantitative polymerase chain reaction.

\section{Case descriptions}

Overall the male/female ratio of cases reported to GeoSentinel was 9:1 and the traveller's age was $41.3 \pm 10.7$ (mean $\pm S D$ ) years.

All cases presented with an acute febrile illness and symptoms suggestive of classic dengue, including headache and joint pain. In three of the 10 cases a rash was reported. Laboratory studies during the febrile period revealed leucopenia (range: 1.2-2.9 × 109/L, norm: 4.0-10.0 x 10\%/L) and thrombocytopenia (range: $13-124 \times 10^{9} / \mathrm{L}$, norm: $\left.140-440 \times 10^{9} / \mathrm{L}\right)$ in all the cases. None of the cases had features of severe dengue and all recovered without complications.

Dengue diagnosis was confirmed by one or more of three methods; non-structural protein 1 (NS1) antigen, DENV IgM enzyme-linked immunosorbent assay (ELISA) serology or DENV viraemia by quantitative (Qt)PCR (Table). DENV IgM was detected in all 10 cases, whereas five cases also tested positive for NS1 antigen. For all these latter cases except one from Germany (Table), NS1 antigen and DENV IgM were detected in a single sample. For the German case, a blood sample drawn at four days post symptom onset was NS1 antigen positive but seroconversion was verified in subsequent samples. In two viraemic Israeli patients, Qt-PCR revealed the virus to be DENV-1 similar to the imported cases seen in Portugal [2].

\section{Discussion}

Dengue has long been known to exist in Africa, but its epidemiology is poorly documented. Recent prediction models of dengue suggest that the true burden of dengue in Africa may approach that of South America [10]. Moreover, limited serological surveys in locations such as Burkina Faso [11] have suggested that the disease is far more prevalent than previously recognised. In the last four years, large dengue epidemics were reported on Macaronesian islands of Cape Verde (DENV-3) [12] and Madeira (DENV-1) [13] off the northwest African coast. Common models of dengue epidemiology suggest that clinically diagnosed cases of classic dengue represent the tip of an iceberg, with actual case numbers being much higher [14].

On 1 April 2013 local health authorities in Luanda reported six cases of dengue fever acquired in the city [15]. The true extent of the dengue outbreak in Luanda is likely to be much higher than currently acknowledged. Anecdotally, returning Israeli travellers with dengue have maintained that multiple additional cases of similar febrile illness were extant in the expatriate community in Luanda.

The origin of the present DENV-1 strain responsible for the current Luanda outbreak is as yet undetermined, but the possibility of an imported strain is of concern. Of the 190,000 ill returned travellers in the GeoSentinel database since 1997, no previous cases of dengue acquired in Angola have been reported. Strains of DENV appear to be circulating between east Africa and the Indian subcontinent [16] and recent DENV-1 isolates from Madeira appear to be closely related to strains circulating in Central or South America $[17,18]$. Thus, it is well established that dissemination of dengue from DENV endemic countries in America and Asia occurs both in east Africa and off the northwest African coast. In this regard, it is important to note that according to the World Tourism Organization (WTO) data, major source countries of travellers to Angola included DENV 
endemic China and Brazil, with 69,900 and 29,700 travellers respectively during 2011 [19].

Another source of concern is the possibility of the spread of dengue to susceptible countries by returning, viraemic travellers. Aedes albopictus, one of the DENV vectors is currently endemic throughout most of the Mediterranean basin, and has recently been documented as far north as the Netherlands [20]. In Israel for example, the presence of Aedes albopictus in dense population centres, creates prime conditions for a dengue outbreak [21].

At present, health practitioners should be aware of the possibility of dengue in febrile travellers returning from Angola. Such travellers would be best served by clinicians with access to rapid diagnostic tests, and should be advised to implement measures to avoid mosquito bites, for the likely duration of viraemia.

This report serves to illustrate the possible speed of global dissemination of cases from an emerging arboviral epidemic focus, and the potential for introduction of novel viruses or novel strains into receptive countries.

\section{Authors' contributions}

Eli Schwartz - study conception; Eyal Meltzer - Drafting of the article; Marc Mendelson - Critical review and editing of the manuscript; Alan Tooke - Collection of data; Florian Steiner - Critical review and editing of the manuscript, collection of data; Philippe Gautret - Critical review and editing of the manuscript, collection of data; Barbara FriedrichJaenicke - Collection of data; Michael Libman - Critical review and editing of the manuscript, epidemiological data; Hanna Bin - Laboratory analysis; Annelies Wilder-Smith Critical review and editing of the manuscript; Duane J Gubler - Laboratory analysis, critical review and editing of the manuscript; David O. Freedman - draft editing, and patient classification; Philippe Parola - Critical review and editing of the manuscript. David O. Freedman and Philippe Parola, also linked the cases together using the GeoSentinel system.

\section{Conflict of interest}

None declared.

\section{References}

1. Freedman DO, Weld LH, Kozarsky PE, Fisk T, Robins R, Von Sonnenburg F, et al. Spectrum of disease and relation to place of exposure among ill returned travelers. N Engl J Med. 2006;354(2):119-30. http://dx.doi.org/10.1056/NEJMoa051331 PMid:16407507

2. ProMED-mail. Dengue/DHF Update (31): Asia, Africa, Pacific. Archive Number: 20130420.1660193. 20 Apr 2013. Available from: http://www.promedmail.org

3. Kokernot RH, Casaca VM, Weinbren MP, Mclntosh BM. Survey for antibodies against arthropod-borne viruses in the sera of indigenous residents of Angola. Trans $R$ Soc Trop Med Hyg. 1965;59(5):563-70. http://dx.doi. org/10.1016/0035-9203(65)90159-8
4. Filipe AF, Pinto MR. Arbovirus studies in Luanda, Angola. 2. Virological and serological studies during an outbreak of dengue-like disease caused by the Chikungunya virus. Bull World Health Organ. 1973;49(1):37-40. PMid:4545155 PMCid:2481088

5. Bakker RC, Veenstra J, Dingemans-Dumas AM, Wetsteyn JCFM, Kager PA. Imported Dengue in The Netherlands. J Travel Med. 1996;3(4):204-8. http://dx.doi.org/10.1111/j.1708-8305.1996. tbo0747.x PMid:9815457

6. Vasconcelos PF, Travassos da Rosa ES, Travassos da Rosa JF, de Freitas RB, Dégallier N, Rodrigues SG, et al. Epidemia de febre clássica de dengue causada pelo sorotipo $2 \mathrm{em}$ Araguaiana, Tocantins, Brasil. [Outbreak of classical fever of dengue caused by serotype 2 in Araguaiana, Tocantins, Brazil]. Rev Inst Med Trop São Paulo. 1993;35(2):141-8. Portuguese. ttp://dx.doi.org/10.1590/So036-46651993000200005 PMid:8284598

7. Gautret P, Simon F, Hervius Askling H, Bouchaud O, LeparcGoffart I, Ninove L, et al. Dengue type 3 virus infections in European travellers returning from the Comoros and Zanzibar, February-April 2010. Euro Surveill. 2010;15(15):pii=19541. Available from: http://www.eurosurveillance.org/ViewArticle. aspx?Articleld $=19541$

8. Gautret P, Botelho-Nevers E, Charrel RN, Parola P. Dengue virus infections in travellers returning from Benin to France, July-August 2010. Euro Surveill. 2010;15(36):pii=19657. Available from: http://www.eurosurveillance.org/ViewArticle. aspx?Articleld $=19657$

9. Amarasinghe A, Kuritsk JN, Letson GW, Margolis HS. Dengue virus infection in Africa. Emerg Infect Dis. 2011;17(8):1349-54. PMid:21801609 PMCid:3381573

10. Bhatt S, Gething PW, Brady OJ, Messina JP, Farlow AW, Moyes $\mathrm{CL}$, et al. The global distribution and burden of dengue. Nature. 2013;496(7446):504-7. http://dx.doi.org/10.1038/nature12060 PMid:23563266

11. Collenberg E, Ouedraogo T, Ganamé J, Fickenscher H, KynastWolf G, Becher H, et al. Seroprevalence of Six Different Viruses Among Pregnant Women and Blood Donors in Rural and Urban Burkina Faso: A Comparative Analysis. J Med Virol. 2006;78(5):683-92. http://dx.doi.org/10.1002/jmv.20593 PMid:16555290

12. Dengue fever, Cape Verde. Wkly Epidemiol Rec. 2009;84(45):469. PMid:19899226

13. Sousa CA, Clairouin M, Seixas G, Viveiros B, Novo MT, Silva AC, et al. Ongoing outbreak of dengue type 1 in the Autonomous Region of Madeira, Portugal: preliminary report. Euro Surveill. 2012;17(49):pii=20333. Available from: http:// www.eurosurveillance.org/ViewArticle.aspx?Articleld $=20333$ PMid:23231893

14. Endy TP, Yoon I-K, Mammen MP. Prospective cohort studies of dengue viral transmission and severity of disease. Curr Top Microbiol Immunol. 2010;338:1-13. http://dx.doi. org/10.1007/978-3-642-02215-9_1 PMid:19802574

15. Casos de dengue registados no hospital geral de Luanda. [Dengue cases recorded in the general hospital in Luanda]. ANGONOTÍCIAS. [Accessed 7 May 2013]. Portuguese. Available from: http://www.angonoticias.com/Artigos/item/38122/ casos-de-dengue-registados-no-hospital-geral-de-luanda

16. Messer WB, Gubler DJ, Harris E, Sivananthan K, De Silva AM. Emergence and global spread of a dengue serotype 3 , subtype III virus. Emerg Infect Dis. 2003;9(7):800-9. http://dx.doi. org/10.3201/eido907.030038 PMCid:3023445

17. Alves MJ, Fernandes PL, Amaro F, Osório H, Luz T, Parreira $P$, et al. Clinical presentation and laboratory findings for the first autochthonous cases of dengue fever in Madeira island, Portugal, October 2012. Euro Surveill. 2013;18(6): pii=20398. Available online: http://www.eurosurveillance.org/ViewArticle. aspx?Articleld=20398 PMid:23410256

18. Huhtamo E, Korhonen EM, Vapalahti O. Imported dengue virus serotype 1 from Madeira to Finland 2012. Euro Surveill. 2013;18(8):pii=20405. Available from: http://www. eurosurveillance.org/ViewArticle.aspx?Articleld=20405 PMid:23449230

19. World Tourism Organization. World Tourism Organization [Internet]. Available from: http://www2.unwto.org/en

20. Medlock JM, Hansford KM, Schaffner F, Versteirt V, Hendrickx $\mathrm{G}$, Zeller $\mathrm{H}$, et al. A review of the invasive mosquitoes in Europe: ecology, public health risks, and control options. Vector Borne Zoonotic Dis. 2012;12(6):435-47. http://dx.doi. org/10.1089/vbz.2011.0814 PMid:22448724 PMCid:3366101

21. Leshem E, Bin H, Shalom U, Perkin M, Schwartz E. Risk for emergence of dengue and chikungunya virus in Israel. Emerg Infect Dis. 2012;18(2):345-7. http://dx.doi.org/10.3201/ eid1802.111648 PMid:22305194 PMCid:3310478 